\title{
Масса зерна колоса и масса тысячи зерен как признаки продуктивности у сортов яровой мягкой пшеницы разных групп спелости в условиях лесостепи Приобья
}

\author{
Е.В. Агеева (D) ${ }^{1}$, И.Н. Леонова(D) ${ }^{2}$, И.Е. Лихенко (D) ${ }^{1,2}$, В.В. Советов ${ }^{1}$
}

\begin{abstract}
Аннотация: Подбор и изучение исходного материала - важный этап селекционного процесса, который необходим для выделения источников хозяйственно ценных признаков. В статье приведены данные сравнительного анализа показателей массы зерна колоса и массы 1000 зерен у сортов яровой мягкой пшеницы различных групп спелости в экологических условиях лесостепи Приобья в 2018-2019 гг. В целом погодные условия изучаемых лет были благоприятными для формирования урожая. Обильное выпадение осадков в июне 2018 г. способствовало увеличению продолжительности периода «всходы - колошение» у рассматриваемого набора сортов, а в 2019 г. дефицит осадков и теплая погода в этот же период вегетации привели к более раннему вступлению растений изучаемых генотипов в фазу колошения. Продолжительность вегетационного периода сортообразцов варьировала от 71 (раннеспелый сорт Новосибирская 16 в 2018 г.) до 104 (среднепоздний сорт Велют в 2018 г.) сут. Между продолжительностью вегетационного периода и температурным режимом отмечена высокая достоверная взаимосвязь $(r=0.91-0.94)$. Масса зерна колоса у сортов изучаемого набора в 2018 г. варьировала от 0.83 (Новосибирская 16) до 1.55 (Бэль) г, в 2019 г. - от 0.55 (Новосибирская 31) до 1.00 (Обская 2) г. Масса 1000 зерен колебалась в пределах от 26.8 (сорт Тризо, 2018 г.) до 41.5 (сорт Чернява 13, 2018 г.) г. Перспективными для использования в селекции на высокую продуктивность колоса и массу 1000 зерен отмечены генотипы среднераннего сорта Чернява 13 и среднеспелого сорта Бэль.
\end{abstract}

Ключевые слова: сорт; яровая мягкая пшеница; масса зерна колоса; масса тысячи зерен; вегетационный период.

Благодарности: Экспериментальная работа выполнена при поддержке бюджетного проекта ИЦиГ СО РАН № 0259-2021-0018. Статистическая обработка и оформление результатов проведены при финансовой поддержке гранта РНФ № 16-16-00011-П.

Для цитирования: Агеева Е.В., Леонова И.Н., Лихенко И.Е., Советов В.В. Масса зерна колоса и масса тысячи зерен как признаки продуктивности у сортов яровой мягкой пшеницы разных групп спелости в условиях лесостепи Приобья. Письма в Вавиловский журнал генетики и селекции. 2021;7(1):5-11. DOI 10.18699/LettersVJ2021-7-01 ripening groups in the conditions of the Priob'e steppe

\author{
E.V. Ageeva $\mathbb{D D}^{1} \bowtie$, I.N. Leonova(D) ${ }^{2}$, I.E. Likhenko ${ }^{1,2}{ }^{1,}$, V.V. Sovetov ${ }^{1}$
}

Abstract: The selection and study of the wheat varieties is an important stage in the breeding process, which is necessary to identify the sources of agronomically valuable traits. The article presents the data of a comparative analysis of the ear grain weight and the 1000 grain weight in varieties of spring soft wheat of various groups of ripeness in the ecological conditions of the forest-steppe of the $\mathrm{Ob}$ region for the period 2018-2019. Overall, the weather conditions of the studied years were favorable for the formation of the yield in the varieties of soft spring wheat. Abundant precipitation in June 2018 contributed to an increase in the duration of the sprouting-heading period in the set of varieties under consideration, and in 2019, a lack of precipitation and warm weather during the same growing season contributed to the fact that the plants of the studied genotypes entered the heading phase earlier. In general, the duration of the growing season of the studied varieties varied from 71 (early ripening variety Novosibirskaya 16 in 2018) to 104 (medium late variety Velut in 2018) days. There was a high reliable relationship between the duration of the growing season and the temperature regime $(r=0.91-0.94)$. The grain weight of an ear in the varieties of the studied set varied from 0.83 (Novosibirskaya 16) to

\footnotetext{
Сибирский научно-исследовательский институт растениеводства и селекции - филиал Федерального исследовательского центра Институт цитологии и генетики Сибирского отделения Российской академии наук, р.п. Краснообск, Новосибирская область, Россия

2 Федеральный исследовательский центр Институт цитологии и генетики Сибирского отделения Российской академии наук, Новосибирск, Россия

Siberian Research Institute of Plant Production and Breeding - Branch of the Institute of Cytology and Genetics of Siberian Branch of the Russian Academy of Sciences, Krasnoobsk, Novosibirsk region, Russia

${ }^{2}$ Institute of Cytology and Genetics of Siberian Branch of the Russian Academy of Sciences, Novosibirsk, Russia

凶elenakolomeec@mail.ru

(C) Агеева Е.В., Леонова И.Н., Лихенко И.Е., Советов В.В., 2021
} 
1.55 (Bel) g in 2018, and in 2019 from 0.55 (Novosibirskaya 31) to 1.00 (Obskaya 2) g. Over the years of research, the mass of 1000 grains varied from 26.8 (in the Trizo variety in 2018) to 41.5 (in the Chernyava 13 variety in 2018) g. The mid-early variety Chernyava 13 and the mid-season variety Bel were identified as promising genotypes for use in breeding for high ear productivity and 1000 grain weight. Key words: variety; spring soft wheat; ear grain weight; 1000 grain weight; vegetation period.

For citation: Ageeva E.V., Leonova I.N., Likhenko I.E., Sovetov V.V. The ear grain weight and the thousand grain weight as productivity traits in varieties of spring bread wheat of different ripening groups in the conditions of the Priob'e steppe. Pisma v Vavilovskii Zhurnal Genetiki i Selektsii = Letters to Vavilov Journal of Genetics and Breeding. 2021;7(1):5-11. DOI 10.18699/LettersVJ2021-7-01 (in Russian)

\section{Введение}

Яровая мягкая пшеница является одной из наиболее важных зерновых культур, выращиваемых в Западно-Сибирском регионе. Площади посевов яровой пшеницы насчитывают 12.3 млн гектаров, что составляет более 15\% всех посевов в Российской Федерации'. Новосибирская область входит в двадцатку крупнейших регионов по посевным площадям пшеницы (Силаева, Баринова, 2019)2. Урожайность мягкой пшеницы значительно зависит от устойчивости генотипов к биотическим (болезни, насекомые) и абиотическим (засуха, засоление) факторам, что в свою очередь влияет на степень адаптивности и экологической пластичности сорта (Bell et al., 1995; Morgounov et al., 2010).

Непосредственное влияние на урожайность пшеницы оказывает продуктивность колоса, при этом степень продуктивности колоса зависит от проявления генетических факторов, детерминирующих признаки, в различных условиях вегетации растений (Цильке, 2005; Лепехов, Коробейников, 2013). В качестве элементов структуры продуктивности колоса оценивают такие параметры, как число фертильных и стерильных колосков в колосе, степень озерненности колоска и главного колоса, масса зерна с колоса и масса 1000 зерен. В условиях континентального климата Западной Сибири для повышения урожайности яровой мягкой пшеницы основное значение придают массе зерна колоса и массе 1000 зерен (Пискарев и др., 2016).

На адаптивность яровой мягкой пшеницы и возможность защиты ее растений от неблагоприятных факторов среды существенно влияет продолжительность вегетационного периода. Значимость продолжительности вегетационного периода возрастает в условиях континентального климата и нестабильных погодных условий Западной Сибири, сопровождающихся весенней засухой и ранним наступлением холодов в начале осени. Установлено, что позднеспелые сорта яровой пшеницы не всегда успевают созреть до наступления ранних осенних заморозков (Шаманин и др., 2017). В то же время раннеспелые сорта утрачивают способность использовать благоприятные условия, которые наступают после окончания весенне-летней засухи, поскольку основные этапы органогенеза пройдены (Лубнин, Советов, 1999).

Важным этапом селекционного процесса являются подбор и изучение исходного материала в различных условиях вегетации для выделения источников, характеризующихся

\footnotetext{
${ }^{1}$ Посевные площади пшеницы в России. Итоги 2019 года. Агровестник; 2019 [обновлено 21 августа 2019; процитировано 29 июля 2020]. ДоступHO: https://www.agrovesti.net

2 Об итогах работы агропромышленного комплекса Новосибирской области за 2019 год. Агровестник; 2020 [обновлено 24 мая 2020; процитировано 29 июля 2020]. Доступно: https://www.agrovesti.net
}

ценными в хозяйственном отношении признаками. В связи с тем что основной вклад в урожайность яровой мягкой пшеницы вносят такие признаки, как масса зерна колоса и масса 1000 зерен, для создания новых сортов необходимо иметь источники, характеризующиеся высокой выраженностью этих признаков. Цель данной работы - изучение количественных признаков «масса зерна колоса» и «масса 1000 зерен» у сортообразцов яровой мягкой пшеницы различных групп спелости для выявления генотипов, наиболее адаптированных к эколого-климатическим условиям региона и сочетающих высокие значения этих показателей.

\section{Материалы и методы}

Исследования проведены в 2018-2019 гг. на опытном поле лаборатории селекции, семеноводства и технологии возделывания полевых культур СибНИИРС - филиала ИЦиГ СО РАН (Новосибирская область).

Почвенный покров опытного поля представлен черноземом выщелоченным среднемощным малогумусным среднесуглинистым. Содержание гумуса составляет $4.2 \%$, общего азота - 0.34\%, подвижного фосфора и калия по Чирикову 29 и 13 мг/100 г почвы соответственно, pH - 6.7-6.8, глубина пахотного слоя - 41-46 см.

Материалом исследований служили 11 сортов яровой мягкой пшеницы отечественной селекции различных групп спелости, большинство из которых рекомендованы для выращивания в Западно-Сибирском регионе (табл. 1). Опыт закладывался по общепринятой методике (Методика государственного сортоиспытания..., 1989). Посев проводился во второй декаде мая, площадь опытной делянки $2 \mathrm{M}^{2}$, повторность - двукратная, размещение - систематическое.

В полевых условиях во время фенологических наблюдений отмечены даты наступления основных фаз развития растений. Корреляционный анализ данных проводили по Б.А. Доспехову (1985) с использованием Microsoft Office Excel 2013. Сравнение образцов по признакам с целью выделения лучших выполняли по 9-балльной системе выражения количественных признаков, применяемой в отделе генетических ресурсов пшеницы ВИР (Зуев и др., 1999; Пискарев и др., 2018), где 9 - самое высокое, 7 - высокое, 5 - среднее, 3 - низкое, 1 - самое низкое значение признака. Принцип расчетов был следующим: для каждого признака в пределах одного года исследований определяли максимальные и минимальные значения, разницу делили на пять, находили интервал балла. Для установления лучших образцов по отдельным селекционно ценным признакам использовали средний балл, рассчитанный как среднее арифметическое 
Таблица 1. Исследованные сортообразцы яровой мягкой пшеницы, группа спелости и происхождение

\begin{tabular}{|c|c|c|}
\hline Образец & Группа спелости & Оригинатор \\
\hline Новосибирская 15 & \multirow{2}{*}{ Раннеспелый } & \multirow{2}{*}{ СиБНИИРС - филиал ИЦиГ СО РАН } \\
\hline Новосибирская 16 & & \\
\hline Новосибирская 29 & \multirow{3}{*}{ Среднеранний } & СиБНИИРС - филиал ИЦиГ СО РАН \\
\hline Чернява 13 & & Тюменский научный центр СО РАН \\
\hline Новосибирская 31 & & СиБНИИРС - филиал ИЦиГ СО РАН \\
\hline Бэль & \multirow{4}{*}{ Среднеспелый } & СиБНИИРС - филиал ИЦиГ СО РАН \\
\hline Обская 2 & & СиБНИИРС - филиал ИЦиГ СО РАН \\
\hline Саратовская 29 & & ФАНЦ Юго-Востока \\
\hline Новосибирская 18 & & СиБНИИРС - филиал ИЦиГ СО РАН \\
\hline Тризо & \multirow{2}{*}{ Среднепоздний } & Deutsche Saatveredelung AG (DSV), Германия \\
\hline Велют & & ИЦиГ СО РАН \\
\hline
\end{tabular}

за конкретные годы изучения. Для статистического анализа брали по 25 растений каждого сорта.

Погодные условия изучаемых лет сложились благоприятно для формирования урожая у сортов мягкой яровой пшеницы (рис. 1, 2). За летний период в 2018 г. выпало 380.3 мм осадков, в 2019 г. - 194.7 мм, тогда как среднемноголетнее значение составляет $220.0 \mathrm{~mm}$.

В начале вегетации в 2018 г. наблюдалась холодная и дождливая погода. В мае отклонение от среднемноголетнего значения температуры составило $4{ }^{\circ} \mathrm{C}$, гидротермический коэффициент Г.Т. Селянинова (ГТК) > 2. В первую половину вегетации превышение количества выпавших осадков в среднем за два месяца было более $80 \%$ среднемноголетних данных (211.4 мм). Наиболее дождливым в этот год оказался июнь - 130.2 мм осадков (ГТК = 2.8). В то же время в июне зафиксирована жаркая погода: показания температуры воздуха были выше среднемноголетних значений на $2.2^{\circ} \mathrm{C}$. Во второй половине вегетации не наблюдалось таких резких перепадов температурного режима, лишь в августе отмечен дефицит осадков (49.7\% среднемноголетних значений, ГТК $=0.4$ ).

В 2019 г. также отмечены неравномерное выпадение осадков и заметное колебание температуры в конце вегетации. Дождливая погода зафиксирована в мае (43.2 мм осадков) и июле (89.9 мм), в июне и августе недобор осадков в среднем составил 50\% (ГТК 0.7 и 0.5 соответственно). Нарастание температуры установлено в третьей декаде июля и сохранялось в первой декаде августа - 19-21 ${ }^{\circ} \mathrm{C}$. В среднем отклонение от среднемноголетних значений температуры воздуха в июле составило $+0.4^{\circ} \mathrm{C}$, в августе $+2.2^{\circ} \mathrm{C}$.

\section{Результаты и обсуждение}

Вегетационный период. Огромное значение при формировании урожайности растения имеет период от всходов до колошения. В ряде работ показано, что обеспеченность влагой растений пшеницы в период формирования трубки и колошения является определяющим для формирования урожая фактором (Добротворская и др., 2013; Лазарев, Скипин, 2013; Волкова, 2016). Варьирование продолжительности периода «всходы - колошение» у изучаемых генотипов было в пределах 33-48 сут, при этом отмечены существенные различия в сроках колошения между образцами (табл. 2). Наиболее продолжительный период «всходы - колошение» как в 2018 г., так и 2019 г. наблюдался у сорта Велют (47 и 48 сут соответственно). У большинства образцов наступление фазы колошения отмечено за 39-41 сут, лишь у раннеспелых сортов Новосибирская 15 и Новосибирская 16 продолжительность фазы составила от 33 до 35 сут.

Обильное выпадение осадков в первой половине вегетации 2018 г. (особенно в июне) способствовало увеличению продолжительности периода «всходы - колошение» у рассматриваемых сортов, а в 2019 г. дефицит осадков и теплая погода в этот же период вегетации (июнь) привели к более раннему вступлению растений изучаемых генотипов в фазу колошения.

По одной из предложенных моделей сорта для лесостепной зоны оптимальная продолжительность вегетационного периода составляет 75-88 сут (Гончаров Н.П., Гончаров П.Л., 2009). Продолжительность вегетационного периода изученных сортообразцов варьировала от 71 (раннеспелый сорт Новосибирская 16 в 2018 г.) до 104 (среднепоздний сорт Велют в 2018 г.) сут. Несмотря на такой диапазон продолжительности вегетационного периода, все генотипы смогли сформировать урожай в условиях лесостепи Приобья за оба года изучения. Между продолжительностью вегетационного периода и температурным режимом отмечена высокая достоверная взаимосвязь. Величина коэффициента корреляции в 2018 г. составила 0.94, в 2019 г. - 0.91. Высокая взаимосвязь также установлена между продолжительностью вегетационного периода и количеством осадков ( $r=0.72$ и 0.87 соответственно).

Наибольший интерес для Западной Сибири представляют сорта с коротким вегетационным периодом, способные сочетать оптимальные сроки созревания и урожайность. В связи с этим при сравнении образцов по системе селекционно ценных признаков, применяемой в ВИР, максимальный балл (9) присваивался сортам, рано входившим в фазы колошения и созревания. В результате обильного выпадения осадков в первый год исследования большинство генотипов при оценке по системе селекционно ценных признаков 
Таблица 2. Продолжительность периодов «Всходы - колошение» и «Всходы - созревание» у сортов яровой мягкой пшеницы (2018-2019 гг.)

\begin{tabular}{lllll}
\hline \multirow{2}{*}{ Сорт } & \multicolumn{2}{l}{ Всходы - колошение } & \multicolumn{2}{l}{ Всходы - созревание } \\
\cline { 2 - 5 } & Сутки & Балл & Сутки & Балл \\
\hline Новосибирская 15 & 35.0 & 9.0 & 73.0 & 9.0 \\
\hline Новосибирская 16 & 34.0 & 9.0 & 72.0 & 9.0 \\
\hline Новосибирская 29 & 39.5 & 7.0 & 84.5 & 5.0 \\
\hline Чернява 13 & 40.0 & 6.0 & 87.0 & 4.0 \\
\hline Новосибирская 31 & 41.5 & 5.0 & 83.5 & 6.0 \\
\hline Бэль & 39.5 & 6.0 & 83.5 & 6.0 \\
\hline Обская 2 & 40.5 & 6.0 & 89.0 & 4.0 \\
\hline Саратовская 29 & 40.0 & 6.0 & 86.5 & 4.0 \\
\hline Новосибирская 18 & 39.0 & 7.0 & 83.0 & 6.0 \\
\hline Тризо & 41.0 & 5.0 & 86.0 & 5.0 \\
\hline Велют & 47.5 & 1.0 & 97.5 & 1.0 \\
\hline Среднее & 39.8 & - & 84.1 & - \\
\hline НСР & 3.5 & - & 5.9 & - \\
\hline
\end{tabular}

Примечание: здесь и далее в табл. 3 представлено среднее значение признака за исследуемый период

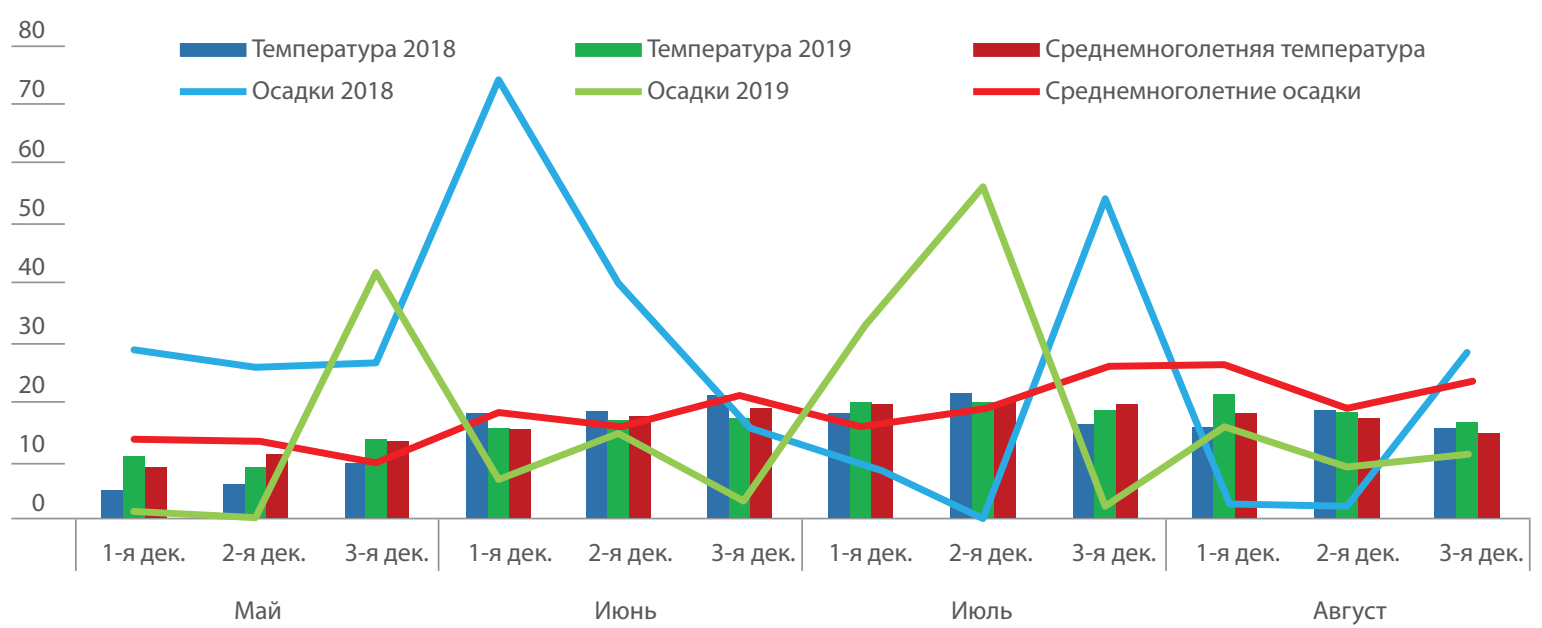

Рис. 1. Метеорологические условия вегетационных периодов 2018-2019 гг. (по данным гидрометеостанции пос. Огурцово, Новосибирская область)

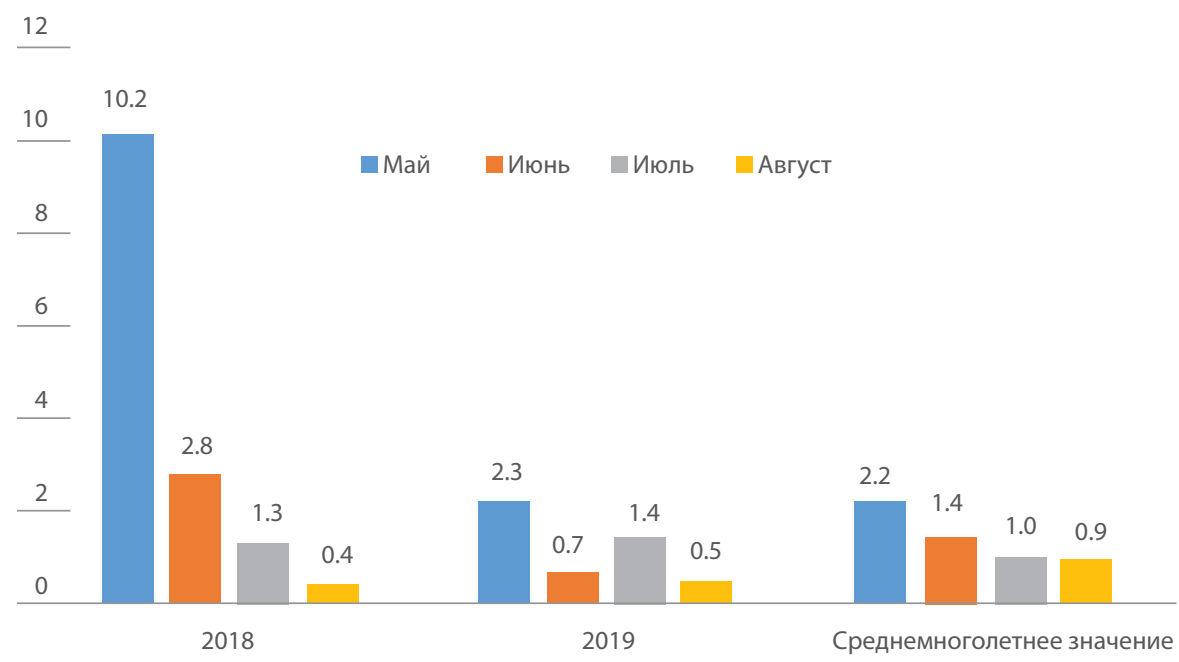

Рис. 2. Гидротермический коэффициент Г.Т. Селянинова за вегетационные периоды 2018-2019 гг. 
$a$

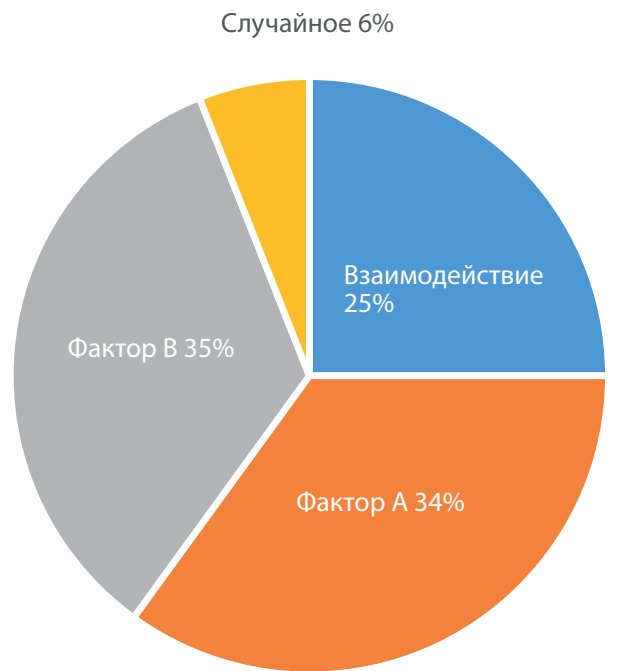

6

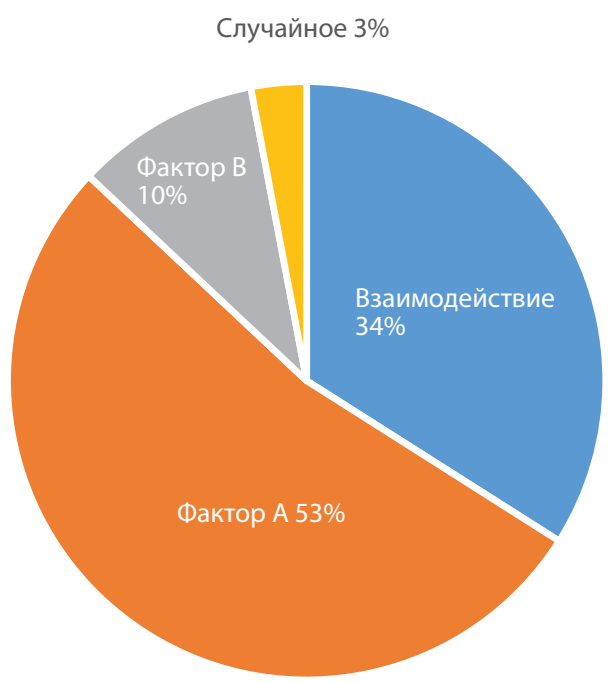

Рис. 3. Результаты дисперсионного анализа данных массы зерна колоса (а) и массы 1000 зерен (б) у сортов яровой мягкой пшеницы. Факторы А и В указывают на влияние генотипа и условий внешней среды соответственно на фенотипическое проявление признаков

попали в группу со средним (Бэль, Новосибирская 31, Новосибирская 18 и Саратовская 29) или низким (Новосибирская 29, Чернява 13, Тризо и Обская 2) значением. В 2019 г. в эти группы вошли всего четыре образца: Чернява 13 (81 сут), Обская 2 (81 сут), Тризо (81 сут) и Саратовская 29 (85 сут). Минимальный балл за период изучения продемонстрировал сорт Велют с вегетационным периодом 91-104 сут.

Средние баллы по продолжительности периода от всходов до созревания за оба года исследований с высоким средним баллом (9-7 баллов) имели местные раннеспелые и среднеспелые сорта (Новосибирская 15, Новосибирская 16 и Новосибирская 18).

Масса зерна колоса. Оптимальная масса зерна колоса, по мнению Н.П. Гончарова и П.Л. Гончарова (2009), составляет 0.8-1.0 г. Масса зерна колоса у изучаемых сортов в 2018 г. варьировала от 0.83 (Новосибирская 16) до 1.55 (Бэль) г, в 2019 г. - от 0.55 (Новосибирская 31) до 1.00 (Обская 2) г.

Достоверное превышение средней массы зерна колоса отмечено у генотипов Бэль (1.19 г) и Чернява 13 (1.08 г), но масса зерна колоса у этих сортов значительно варьировала за годы исследований (табл. 3).

Масса зерна колоса у сортов Новосибирская 15, Новосибирская 29, Бэль, Чернява 13, Обская 2 и Велют в условиях вегетационного периода 2018 г. была значительно выше, чем в 2019 г. У скороспелых сортов под воздействием колебаний температур за вегетацию масса зерна колоса меняется в меньшей степени, чем у среднеспелых и позднеспелых (Пискарев и др., 2010), что наблюдалось в проведенном эксперименте. Разница по признаку в пределах одного сорта составила от 0.33 (Новосибирская 15) до 0.73 (Бэль) г.

Следует выделить сорт Обская 2, у которого масса зерна колоса в 2019 г. была выше полученной массы зерна колоса в 2018 г. на 0.2 г и составила 1 г, что является благоприятным вкладом в урожайность сорта.

Высоким средним за годы изучения баллом (8-9) при оценке массы зерна колоса характеризовались 7 образцов, исходя из этого они представляют интерес для селекции по данному признаку.

Двухфакторный дисперсионный анализ данных массы зерна колоса (рис. 3, а) показал, что вклад изменчивости, вызванный условиями выращивания (фактор В), составляет 35\%, а генотипическая изменчивость (фактор А) и взаимодействие факторов А и В - 34 и 25\% соответственно от общего фенотипического варьирования признака. В то же время на долю изменчивости, вызванной случайными факторами, приходится 6\%, что может быть связано с агротехническими условиями.

Macca 1000 зерен также играет существенную роль в формировании продуктивности колоса. За годы исследований данный признак варьировал от 26.8 (у сорта Тризо в 2018 г.) до 41.5 (у сорта Чернява 13 в 2018 г.) г. В 2018 г. массой 1000 зерен выделились сортообразцы Бэль (37.2 г), Чернява 13 (41.5 г) и Новосибирская 18 (35.3 г), в 2019 г. Бэль (36.5 г), Чернява 13 (36.5 г), Новосибирская 16 (36.6 г) и Саратовская 29 (37.8г).

Величина массы 1000 зерен зависит не только от условий среды, но и сортовой специфики, о чем свидетельствуют показатели у сортов Обская 2 и Новосибирская 18, у которых за исследуемый период масса 1000 зерен была неизменной и высокой - 39.7 и 35.5 г. соответственно.

Несмотря на нестабильные погодные условия, в 2019 г. в среднем у большинства сортов наблюдалось формирование более крупного зерна (34.7 г), чем в 2018 г. (33.9 г). Возможно, это связано с тем, что во второй половине вегетации второго года исследований сложились более благоприятные условия для интенсивной работы фотосинтетического аппарата и аккумуляции накопленных продуктов фотосинтеза в зерне.

В среднем раннеспелые сорта (Новосибирская 15 и Новосибирская 16) превосходили по массе 1000 зерен такие сорта, как Тризо, Новосибирская 31 и Велют. Среднюю и выше средней массу 1000 зерен (4-8) имели 7 образцов. 
Таблица 3. Масса зерна колоса и масса 1000 зерен у сортов яровой мягкой пшеницы (2018-2019 гг.)

\begin{tabular}{|c|c|c|c|c|}
\hline \multirow{2}{*}{ Сорт } & \multicolumn{2}{|c|}{ Масса зерна колоса } & \multicolumn{2}{|c|}{ Масса 1000 зерен } \\
\hline & Грамм & Балл & Грамм & Балл \\
\hline Новосибирская 15 & 0.84 & 7.0 & 32.3 & 4.0 \\
\hline Новосибирская 16 & 0.76 & 6.0 & 34.8 & 5.0 \\
\hline Новосибирская 29 & 0.87 & 8.0 & 33.9 & 3.0 \\
\hline Чернява 13 & 1.08 & 9.0 & 39.0 & 8.0 \\
\hline Новосибирская 31 & 0.72 & 6.0 & 30.5 & 2.0 \\
\hline Бэль & 1.19 & 9.0 & 36.9 & 6.0 \\
\hline Обская 2 & 0.90 & 8.0 & 39.7 & 8.0 \\
\hline Саратовская 29 & 0.92 & 8.0 & 33.2 & 5.0 \\
\hline Новосибирская 18 & 0.96 & 8.0 & 35.5 & 4.0 \\
\hline Тризо & 0.75 & 7.0 & 30.8 & 2.0 \\
\hline Велют & 0.98 & 8.0 & 30.7 & 2.0 \\
\hline Среднее & 0.90 & - & 34.3 & - \\
\hline $\mathrm{HCP}_{05}$ & 0.1 & & 1.3 & \\
\hline
\end{tabular}

Результаты двухфакторного дисперсионного анализа массы 1000 зерен показали, что вклад изменчивости, вызванный условиями выращивания (фактор В), составляет $10 \%$, что значительно меньше, чем изменчивость, обусловленная влиянием генотипа (фактор A, 53\%) (см. рис. 3, б). Взаимодействие факторов А и В составило 34\% общего фенотипического варьирования признака.

Сравнение сортов по степени выраженности обоих признаков показывает, что сорта среднепоздней группы спелости характеризировались значительно меньшими показателями массы 1000 зерен, при этом не уступали другим сортам по массе зерна колоса. Данные других авторов также свидетельствуют, что выраженность элементов продуктивности (число зерновок, масса зерна колоса, урожайность) ниже у среднепоздних сортов по сравнению со среднеранними при выращивании в различных регионах Западной Сибири (Беляев, Соколова, 2015; Бойко и др., 2015).

\section{Заключение}

Значительный интерес в условиях лесостепи Новосибирской области представляют сорта, способные за короткий вегетационный период сформировать колос с высокой продуктивностью и крупностью зерна. Оптимальное сочетание показателей изученных признаков выявлено для сортов среднеранней и среднеспелой групп спелости. Сортообразцами, сочетающими высокие показатели массы зерна колоса и массы 1000 зерен, являются среднеранний сорт Чернява 13 и среднеспелый сорт Бэль. Эти сорта можно рекомендовать в качестве перспективных генотипов для использования в селекции на высокую продуктивность колоса и массу 1000 зерен.

\section{Список литературы / References}

Беляев В.И., Соколова Л.В. Изменчивость урожайности яровой мягкой пшеницы различных групп спелости в Восточно-Кулундинской зоне Алтайского края. Вестник АГАУ. 2015;4(126):16-21.
[Belyaev V.I., Sokolova L.V. Yield variation of spring soft wheat varieties of different maturity groups in the East-Kulundinskaya zone of the Altai region. Vestnik Altayskogo Gosudarstvennogo Agrarnogo Universiteta $=$ Bulletin of the Altai State Agricultural University. 2015;4(126):16-21. (in Russian)]

Бойко Н.И., Пискарев В.В., Тимофеев А.А. Особенности формирования урожайности пшеницы мягкой яровой в контрастных условиях лесостепи Приобья. Вестник АПК Ставрополья. 2015;3(19):135-141.

[Boyko N.I., Piskarev V.V., Timofeev A.A. Features of formation of soft spring wheat yield in the contrasting weather conditions of foreststeppe Ob' region. Vestnik APK Stavropol'ya = Agricultural Bulletin of Stavropol Region. 2015;3(19):135-141. (in Russian)]

Волкова Л.В. Урожайность яровой мягкой пшеницы и ее связь с элементами продуктивности в разные по метеорологическим условиям годы. Аграрная наука Евро-Северо-Востока. 2016;6(55):9-14. [Volkova L.V. Productivity of spring wheat and its relation to elements of yield structure in years differ by meteorological conditions. Agrarnaya Nauka Evro-Severo-Vostoka = Agricultural Science EuroNorth-East. 2016;6(55):9-14. (in Russian)]

Гончаров Н.П., Гончаров П.Л. Методические основы селекции растений. Новосибирск: Акад. изд-во «Гео», 2009.

[Goncharov N.P., Goncharov P.L. Methodical Bases of Plant Breeding. Novosibirsk: Acad. Publ. House "Geo", 2009. (in Russian)]

Добротворская Н.И., Каличкин В.К., Сорокина О.Л. Влияние гидротермических условий на урожайность и качество зерна яровой пшеницы в лесостепи Новосибирского Приобья. Достижения науки и техники АПК. 2013;(12):16-18.

[Dobrotvorskaya N.I., KaMchkin V.K., Sorokina O.L. Effect of hydrothermal conditions on yield and grain quality of spring wheat in the forest steppe of Novosibirsk Ob region. Dostizheniya Nauki i Tekhniki APK = Achievements of Science and Technology of AIC. 2013;(12):16-18. (in Russian)]

Доспехов Б.А. Методика полевого опыта М.: Агропромиздат, 1985;269-297.

[Dospekhov B.A. Field experiment technique. Moscow: Agropromizdat Publ., 1985;269-297. (in Russian)]

Зуев Е.В., Ляпунова О.А., Брыкова А.Н., Сурганова Л.Д., Никифоров М.Н., Разумова И.И., Плотникова Л.Н., Потокина С.Н., Бородина Р.К., Иванова О.А., Кожушко Н.Н., Жукова А.Э., Чмелева 3.В., Климентьева Н.Ф. Характер изменчивости скороспелых образцов яровой мягкой пшеницы в различных эколого-географических условиях. Каталог мировой коллекции ВИР. СПб.: ВИР, 1999;708:67. 
[Zuev E.V., Lyapunova O.A., Brykova A.N., Surganova L.D., Nikiforov M.N., Razumova I.I., Plotnikova L.N., Potokina S.N., Borodina R.K., Ivanova O.A., Kozhushko N.N., Zhukova A.E., Chmeleva Z.V., Kliment'eva N.F. The pattern of variability of early-ripening soft spring wheat accessions under various ecogeographical conditions. VIR World Collection Catalogue. St. Petersburg: VIR Publ., 1999;708:67. (in Russian)]

Лазарев А.П., Скипин Л.Н. Возможности использования климатического фактора на черноземах Западной Сибири. Вестник КрасГАУ. 2013;10(85):59-64.

[Lazarev A.P., Skipin L.N. The climatic factor use possibilities on the Western Siberia chernozems. Vestnik KrasGAU = Bulletin of KrasGAU. 2013;10(85):59-64. (in Russian)]

Лепехов С.Б., Коробейников Н.И. Модель урожайных сортов яровой мягкой пшеницы для степной зоны Алтайского края. Сибирский вестник сельскохозяйственной науки. 2013;1(230):23-29.

[Lepekhov S.B., Korobeynikov N.N. Field and agronomic drought resistance of soft wheat varieties in forest-steppe conditions of the Altai region. Sibirskiy Vestnik Selskokhozyaystvennoy Nauki = Siberian Herald of Agricultural Sciences. 2013;1(230):23-29. (in Russian)]

Лубнин А.Н., Советов В.В. Итоги селекционной работы по яровой пшенице, изучение ее растительных ресурсов в зоне селекцентра СибНИИРС за 30 лет (1969-1998). Сибирский вестник сельскохозяйственной науки. 1999;(3-4):70-75.

[Lubnin A.N., Soviets V.V. The results of breeding work on spring wheat, the study of its plant resources in the area of the selection center SibNIIRS for 30 years (1969-1998). Sibirskiy Vestnik Selskokhozyaystvennoy Nauki = Siberian Herald of Agricultural Sciences. 1999;(3-4):70-75. (in Russian)]

Методика государственного сортоиспытания сельскохозяйственных культур / Гос. комисс. по сортоиспытанию с.-х. культур при М-ве с. хоз-ва СССР; под общей ред. В.И. Головачева, Е.В. Кириловской. Москва: Калининская областная типография управления издательств, полиграфии и книжной торговли Калининского облисполкома, 1989.

[Methodology of state variety testing of agricultural crops / State Commission according to variety testing of agricultural products at Ministry with households of the USSR / V.I. Golovachev, E.V. Kirilovskaya (Eds.). Moscow: Kalinin Regional Printing House of the Publishing House, Printing and Book Trade of the Kalinin Regional Executive Committee, 1989. (in Russian)]

Пискарев В.В., Бойко Н.И., Кондратьева И.В. Источники хозяйственно ценных признаков для селекции пшеницы мягкой яровой (Triticum Aestivum L.) в условиях лесостепи Приобья Новосибирской области. Вавиловский журнал генетики и селекции. 2016;20(3):277-285.

[Piskarev V.V., Boyko N.I., Kondratyeva I.V. Sources of economically valuable traits for breeding soft spring wheat (Triticum Aestivum L.) in the forest-steppe conditions of the Ob region of the Novosibirsk region. Vavilovskii Zhurnal Genetiki $i$ Selektsii = Vavilov Journal of Genetics and Breeding. 2016;20(3):277-285. (in Russian)]
Пискарев В.В., Зуев Е.В., Брыкова А.Н. Исходный материал для селекции яровой мягкой пшеницы в условиях Новосибирской области. Вавиловский журнал генетики и селекции. 2018;22(7):784-794. DOI 10.18699/VJ18.422.

[Piskarev V.V., Zuev E.V., Brykova A.N. Sources for the breeding of soft spring wheat in the conditions of Novosibirsk region. Vavilovskii Zhurnal Genetiki i Selektsii = Vavilov Journal of Genetics and Breeding. 2018;22(7):784-794. DOI 10.18699/VJ18.422. (in Russian)]

Пискарев В.В., Цильке Р.А., Москаленко В.М., Тимофеев А.А. Изменчивость и наследование количественных признаков мягкой яровой пшеницы в контрастных эколого-климатических условиях Западной Сибири и Северного Казахстана. Новосибирск: ГНУ СибНИИРС СО Россельхозакадемии, 2010.

[Piskarev V.V., Tsilke R.A., Moskalenko V.M., Timofeev A.A. Variation and inheritance of quantitative traits of soft spring wheat in contrasting ecological and climatic conditions of Western Siberia and Northern Kazakhstan. Novosibirsk: State Scientific Institution SibNIIRS SB Russian Agricultural Academy, 2010. (in Russian)]

Силаева Л.П., Баринова Е.В. Современное состояние и условия рационального размещения производства пшеницы. Экономический журнал. 2019;1(53):33-42. DOI 10.24411/2072-8220-201900003.

[Silaeva L.P., Barinova E.V. The current state and conditions for the rational distribution of wheat production. Ekonomichesky zhurnal. 2019;1(53):33-42. DOI 10.24411/2072-8220-2019-00003. (in Russian)]

Цильке Р.А. Генетические основы селекции мягкой яровой пшеницы на продуктивность в Западной Сибири: монография. Новосибирск: НГАУ, 2005;321.

[Tsilke R.A. Genetic bases of breeding of soft spring wheat for productivity in Western Siberia: Monograph. Novosibirsk: NSAU Publ., 2005;321. (in Russian)]

Шаманин В.П., Потоцкая И.В., Шепелев С.С., Пожерукова В.Е., Трущенко А.Ю., Чурсин А.С., Моргунов А.И. Оценка линий синтетической пшеницы (Triticum durum/Aegilops tauschii) по вегетационному периоду и устойчивости к болезням. Вавиловский журнал генетики и селекции. 2017;21(3):347-353. DOI 10.18699/VJ17.252. [Shamanin V.P., Pototskaya I.V., Shepelev S.S., Pozherukova V.E., Truschenko A.Yu., Chursin A.S., Morgunov A.I. Evaluation of synthetic wheat lines (Triticum durum/Aegilops tauschii) for vegetative period and resistance to diseases. Vavilovskii Zhurnal Genetiki i Selektsii = Vavilov Journal of Genetics and Breeding. 2017;21(3):347353. DOI 10.18699/VJ17.252. (in Russian)]

Bell M.A., Fischer R.A., Byerlee D., Sayre K. Genetic and agronomic contributions to yield gains: a case study for wheat. Field Crops Research. 1995;44:55-65.

Morgounov A., Zykin V., Belan I., Roseeva L., Zelenskiy Yu., Hugo Ferney Gomez-Becerrad, Budakd H., Bekes F. Genetic gains for grain yield in high latitude spring wheat grown in Western Siberia in 1900-2008. Field Crops Research. 2010;117:101-112. DOI 10.1016/j. fcr.2010.02.001. 